\title{
Impact of covid-19 on household food security of red rice farmers dry land in gunungkidul regency
}

\author{
Eka Novri Nur Hasanah, Lestari Rahayu*, and Oki Wijaya \\ Department of Agribusiness, Faculty of Agriculture, University Muhammadiyah Yogyakarta, \\ Yogyakarta, Indonesia
}

\begin{abstract}
Red rice is a staple food and is known as germplasm in Gunungkidul Regency. Panggang District is one of the sub-districts that has low productivity in red rice farming. This study aims to determine the contribution of income, food security, and household welfare levels of dry land red rice farmers before Covid-19 and during Covid-19. This research was conducted in Panggang District which was determined purposively. The number of samples taken using the Slovin formula and obtained 100 respondents for sampling using simple random sampling. The data were analyzed using quantitative analysis in the form of farmer household income analysis, contribution analysis, food security analysis, and welfare analysis. The results showed that there was an impact during Covid-19 on the contribution of farmers' income which decreased. The level of food security of farmer households also has an impact, during Covid-19 the number of households in the food insecure category has increased. The level of welfare of farmer households measured using two indicators, namely the Purchasing Power of Farmers' Households and the Income Exchange Rate of the Perani Household showed the same results, namely the impact during Covid-19 was seen by the increase in households with the category of not being prosperous.
\end{abstract}

\section{Introduction}

\subsection{Background}

Covid-19 emerged in December 2019 and first developed in Wuhan, China. The virus named Severe Acute Respiratory Syndrome Coronavirus 2 (SARS-CoV-2) is a virus that attacks the respiratory system. Covid-19 has spread to almost all countries, including Indonesia. This virus began to spread in Indonesia in March 2020.

The spread that occurred had an impact on the Indonesian economy both in terms of trade, investment, and tourism [1]After the Large-Scale Social Restrictions (PSBB) policy which was implemented in several big cities in Indonesia, people who worked in one area experienced salary cuts or even layoffs. The pandemic has caused anxiety about food

*Corresponding author: lestari@umy.ac.id 
security throughout the world, especially Indonesia, which has significantly disrupted agricultural production and supply chains due to road access closures, transportation restrictions, and reduced processing capacity [2].

Agricultural production and distribution will experience delays. The next thing that will be caused by the spread of Covid-19 is the food crisis. This was discussed at thewarning Food and Agriculture Organization (FAO) which stated that the world was experiencing a food crisis. Therefore, the government formed a long-term food security policy. Keeping the stock of basic needs of the community safe is one of the government's efforts in overcoming the food crisis.

Food is a basic need for every human being. Most of the staple foods of the Indonesian population come from cereals such as rice, corn and wheat[3]. In meeting food needs, it must be seen from the adequacy of the community's staple food, namely rice which has good carbohydrate content to increase energy sources. It can be said to be fulfilled if the occupants of the house are not in a state of hunger. Therefore, increasing food security is a top priority in development because food has an important position.

Food security can be defined as the availability of food for the community in sufficient quantity and quality, distributed at affordable prices and safe for consumption to support daily activities. The food security system was created to ensure that the food supply during the Covid-19 pandemic and during the recovery period after the pandemic remains safe. Food security is closely related to the welfare of the community, especially farmers.

Farmer welfare is the ability of farmers to meet the basic needs of their lives and families such as clothing, food, shelter, education, and health[4]. Farmer households can be said to be prosperous if the proportion of food consumption is below $50 \%$ of the total expenditure and vice versa if it is above $50 \%$ then the farmer household is said to be not prosperous[5].

Rice plants are included in food crops, which are widely cultivated by the people of Indonesia. In Indonesia, types of rice can be distinguished by the color of the rice, namely white rice, red rice, and black rice[6]. Rice plants are not only planted in paddy fields, but rice can also be cultivated in fields or dry land. Utilization of dry land whose existence is quite available. Therefore, dry land is an alternative solution and has the potential to develop food crops. In meeting the food needs of the population, the government is making efforts to increase national rice production. It aims to improve food security.

Gunungkidul Regency is one of the regencies in Yogyakarta Province that conducts rice farming. Most of the land in Gunungkidul is farmland or often referred to as dry land. One of the commodities in Gunungkidul is field rice. Gunungkidul Regency in 2018 most of the rice produced was of the type of field rice with a harvested area of 44,411 ha or equivalent to $74.73 \%$ of the total harvested area[7]. The most widely grown type of rice is red rice. Red rice is one of the plasma nutfah of the Special Region of Yogyakarta and is still cultivated by farmers. Red rice (Oryza nivara) cultivated in Yogyakarta Province has 5 local varieties, namely Mandel, Segreng, Cempo red, Saodah red, and Andel red[8]. Yogyakarta has local red rice that must be developed because over time the demand for red rice is increasing. Two types of red rice paddy local such as upland rice cultivated in the district of Gunungkidul namely Mandel and Segreng. It is well known that red rice has many health benefits, besides that red rice can prevent food and nutritional deficiencies, making it suitable as a food ingredient. Red rice is a source of protein and minerals such as selenium which is useful for increasing the immune system. This rice can also adapt easily to conditions and climates. Red rice has a lot of protein, minerals and fiber which is higher than white rice. Therefore, the price of red rice is higher than white rice. It can be seen in the following Table 1: 
Table 1. Upland rice productivity in Gunungkidul Regency, 2017-2019

\begin{tabular}{|c|c|c|c|}
\hline \multirow[t]{2}{*}{ Subdistrict } & \multicolumn{3}{|c|}{ Productivity $(\mathrm{Ku} / \mathrm{Ha})$} \\
\hline & 2017 & 2018 & 2019 \\
\hline Panggang & 46.95 & 32.89 & 38.30 \\
\hline Purwosari & 36.27 & 50.79 & 47.75 \\
\hline Paliyan & 52.91 & - & 63.32 \\
\hline Saptosari & 40.03 & 38.83 & 55.25 \\
\hline Tepus & 29.25 & 30.66 & 36.10 \\
\hline Tanjungsari & 41.17 & - & 41.02 \\
\hline Rongkop & 43.75 & 46.21 & 51.75 \\
\hline Girisubo & 42.35 & 42.43 & 54.33 \\
\hline Semanu & 44.49 & 54.25 & 65.23 \\
\hline Ponjong & 46.56 & 56.54 & 50.43 \\
\hline Karangmojo & 51.45 & 56.38 & 38.86 \\
\hline Wonosari & 51.68 & 52.49 & 51.61 \\
\hline Playen & 51.41 & - & 65.81 \\
\hline Patuk & 53.47 & - & 41.41 \\
\hline Gedangsari & 45.39 & 52.72 & 69.48 \\
\hline Nglipar & 44.47 & - & 48.00 \\
\hline Ngawen & 50.30 & 53.97 & 45.55 \\
\hline Semin & 49.13 & - & 51.63 \\
\hline
\end{tabular}

Source: [9]

Based on general conditions there are changes in productivity from year to year. The production of red rice cultivated on dry land is expected to increase food security and increase farmers' income in Gunungkidul Regency. This is because the poverty rate in Gunungkidul Regency is $17.12 \%$ in 2018 , this number is greater than the Bantul Regency of $13.43[9]$.

The majority of people in Gunungkidul Regency work as farmers by $57.49 \%{ }^{9}$. The government plays an important role in the development of the red rice agricultural sector by providing assistance in the form of facilities or production inputs to support the production of red rice.

The income earned by the community in addition to being farmers comes from laborers, both skilled and building, employees, civil servants, traders, and others.

Many people use their agricultural products as a means to meet their daily needs, especially the red rice food crop. However, the price of red rice reaches IDR. 15,000 to IDR. 20,000 per kg, which is higher than the price of white rice. If production increases, it can provide large results to the household income of farmers in Gunungkidul Regency. However, judging from several conditions, such as when the Corona epidemic hit Yogyakarta, most of the people consumed their harvests to fulfill their daily lives. It is hoped that the implementation of food security can increase rice production which is able to increase farmers' income, but the production of red rice in Gunungkidul Regency is not optimal. Based on these problems, it is necessary to conduct research on the impact of Covid-19 on household food security of dry land red rice farmers in Gunungkidul Regency. This research aim to: 1) determine the household income contribution of dry land red rice farmers in Gunungkidul Regency before and during Covid-19, 2) determine the food security of dry land red rice farmers' household incomes in Gunungkidul Regency before and during Covid-19, 3) analyze household welfare level of dry land red rice rice farmers in Gunungkidul Regency before and during Covid-19. 


\section{Literature Review}

\subsection{Impact of Covid-19}

Virus with the Latin name Severe Acute Respiratory Syndrome Coronavirus 2 (SARS-CoV2) is a type of virus that attacks the respiratory tract. This virus first appeared in Wuhan, China. The spread of Covid-19 is getting wider, thus disrupting the survival of people in Indonesia. The spread of Covid-19 which has reached various parts of the world has an impact on the Indonesian economy, both from tourism, trade, and investment[1]. The Covid-19 pandemic has created a new era in the supply chain and food industry.

After the lockdown, tracking Covid-19 on the food sector is not a priority for the government, but the approach taken by the government is monitoring food, the production environment and its surroundings[10]. This triggers a shock to global supply for countries that depend on trade in agricultural production, so they must

increase food security to reduce per capita food supply from imports[11]. One of the countries that must maintain food security in the long term when viewed from the Covid-19 case is Indonesia.

Based on the results of research by Patunru said that the price of food commodities, especially rice, increased when the Covid-19 case was first announced in Indonesia in March[12]. The largest rice producer is Central Java with a total production of 5.52 million tons in 2019, which makes farmers in Central Java have to increase their production so that they can become a stock of food needs for other regions.

Immunity is closely related to Covid-19. One of the factors that maintain immunity is eating habits[13]. Poor eating habits and an unbalanced diet result in inhibited immune system response. Therefore, eating habits with a balanced, varied, and safe diet are useful in preventing chronic diseases and strengthening the immune system. After the lockdown, tracking Covid-19 on the food sector is not a priority for the government, but the government's approach is monitoring food, the production environment and its surroundings[10].

\subsection{Red Rice}

Rice rice (Oryza nivara) is a rice variety that has long been developed to meet food needs. Red rice is cultivated without waterlogging from the beginning of planting to harvest, so it is resistant to drought and is often referred to as upland rice[14]. Red rice is preferred over white rice because of its market potential and higher nutritional value[15]. Red rice contains various vitamins such as vitamin $A$, vitamin $E$, vitamin $B$, vitamin $B 6$. The price of red rice is quite high, ranging from IDR 15.000 - IDR 20.000 per $\mathrm{kg}$, which is more expensive than white rice. The carbohydrate content of red rice is $0.1018 \%$ less than white rice which is $0.1342 \%[6]$. In general, red rice is cultivated in paddy fields, but can also be cultivated in fields or often referred to as dry land. Some of the characteristics of dry land are: limited water, easy erosion, land productivity is easy to decline, there is a variety of plants, and technology adoption is still low. So, with the cultivation of this red rice plant, it can increase the production or income of local farmers.

In general, red rice contains better nutrition than white rice. It is possible that people like red rice because it is delicious, fluffier and has an attractive appearance. One of the characteristics of Segreng red rice which is a superior variety in Gunungkidul is that it can improve farmers welfare through Segreng red rice commodities [16]. 


\subsection{Income}

Farming income is the difference between the income and the total costs incurred for a certain period. Income is one indicator to measure the economic capacity of the community, namely the level of income. Factors that affect income are education level, work experience, type of business and location, land area, product price, productivity, pesticides, and others.

The total income of a farmer's household is the total that is obtained from the income that has been calculated from all activities that generate economic value, both in the agricultural and non-agricultural sectors. Farmer household income is divided into 3, as follows:

1. On farm red rice is a source of income from the results of red rice farming which is the main source of income for rice farming households.

2. Off farm is income outside of farming that is still within the scope of agriculture, such as agricultural laborers in other people's gardens or working outside their own farm. For farm households, off-farm activities as farm laborers are a source of additional income.

3. Non-farm is income earned from outside agricultural activities. This source of income comes from civil servants, traders, breeders, and company employees.

\subsection{Contribution}

Contribution is an activity in providing assistance to achieve the desired goal. The contribution can be calculated by comparing the income of the farm run with the total household income. The contribution of farming in previous research by other researchers, there is an increase in the household income of farmers in farming in the yard of IDR $101,920 /$ harvest. The large contribution of income earned by farming families comes from other incomes outside of coconut farming[17]

\subsection{Food Security}

Food security according to the Law of the Republic of Indonesia Number 18 of 2012 concerning conditions where the fulfillment of food needs for the state to individuals can be seen from the availability of sufficient food, both in quantity and quality, nutritious, diverse, equitable, and affordable which does not conflict with religion, belief, and culture in the community so that they can live in a healthy and productive manner in a sustainable manner[18]. Food security have stating that there are three pillars of food security, namely: availability, access, and utilization[19].

Food availability is the condition of the availability of food produced from domestic production, food reserves, as well as food imports as seen from imports and food assistance. Food access is the ability of a household to obtain sufficient and nutritious food. Food utilization is the use of food by households to absorb nutrients including storage, processing, feeding habits for individuals with special dietary needs, health status of household members, and so on. In 2011-2013, an estimated 842 million people suffered from chronic hunger. Food security are identified four pillars of food security such as availability, access, utilization, and stability[20].

\subsection{Welfare}

Welfare is a condition in which a person is fulfilled both materially, socially, and religiously which can be said to be prosperous or prosperous. The level of welfare of 
farmers is one of the important factors in development, especially the agricultural sector. The level of welfare of farmers is expected to decline, this is due to several factors, namely: low prices of grain at harvest time and increased production input factors in farming[21].

The welfare of farmer households is analyzed using five indicators namely 1) The structure of household income both on farm, off farm, and non farm; 2) The structure of household expenditures, both food and non-food expenditures; 3) Household food substitution rate, 4) Farmer household's purchasing power level, and 5) Farmer household income exchange rate (NTP)[22]. Farmer household welfare analysis can be done by using the methods that are Farmer Household Purchasing Power Level (DBPP) and Farmer Household Income Exchange Rate (NTP).

\section{Method}

\subsection{Site of Study}

The research location is in Panggang District, Gunungkidul Regency. Determination of the research location is done purposively. The consideration in choosing the location was in Panggang District because the sub-district is one of the producers of red rice in Gunungkidul Regency. Therefore, it is necessary to conduct research on the impact of Covid-19 on household food security of dry land red rice farmers in Gunungkidul Regency.

\subsection{Respondent Determination}

Respondents taken in this study were red rice farmers in Panggang District. Farmer data was taken in stages, Panggang District has six villages namely Girisekar, Girikarto, Girimulyo, Giriwungu, Giriharjo, and Girisuko villages. From the six villages, four villages were taken, namely Girisekar, Girikarto, Girimulyo, and Giriwungu villages because these villages have large areas of land for cultivating Segreng variety of red rice. The first step is to determine the village based on the land area. The following is data on dry land area by village in Panggang District in 2020.

Table 2. Dry land area in Panggang District by village

\begin{tabular}{|c|l|c|}
\hline No & Village & Dry Land Area (Ha) in 2020 \\
\hline 1 & Giriharjo & 868,26 \\
\hline $\mathbf{2}$ & Giriwungu & $\mathbf{1 , 0 1 5 . 0 5}$ \\
\hline $\mathbf{3}$ & Girimulyo & $\mathbf{1 , 2 4 6 . 9 9}$ \\
\hline $\mathbf{4}$ & Girikarto & $\mathbf{1 , 2 8 5 . 5 6}$ \\
\hline $\mathbf{5}$ & Girisekar & $\mathbf{1 , 4 3 8 . 5 6}$ \\
\hline 6 & Girisuko & 932,11 \\
\hline
\end{tabular}

Table 2 explains that extraction based on village is selected with a land area of more than The average land area in Panggang District is 1,000 hectares. The four selected villages that were cultivated for red rice farming of the Segreng variety were taken from four villages including the villages of Girisekar, Girikarto, Girimulyo, Giriwungu. The second step is based on farmer groups, each village is taken one farmer group that has the most members. The following are farmer groups in the villages of Girisekar, Girikarto, Giriwungu, and Girimulyo. 
Based on Table 2 explains that the sampling of farmers based on farmer groups obtained 199 members. Furthermore, the distribution of the number of farmers from each farmer group will be taken proportionally.

Table 3. Data on the number of samples of red rice farmers

\begin{tabular}{|c|l|c|}
\hline No. & Village & Total \\
\hline 1 & Girisekar & $27 / 199 \times 100=13$ \\
\hline 2 & Girikarto & $73 / 199 \times 100=37$ \\
\hline 3 & Girimulyo & $74 / 199 \times 100=37$ \\
\hline 4 & Giriwungu & $25 / 199 \times 100=13$ \\
\hline \multicolumn{2}{|c|}{ Total } & $\mathbf{1 0 0}$ \\
\hline
\end{tabular}

Based on table 3 it is clear that the total samples taken are each villages, namely 100 samples of farmers. This figure was taken due to the limited ability of researchers in data collection. Respondents were taken using simple random sampling. This method provides equal opportunities for each member of the population which is carried out randomly without regard to the strata in the population by performing calculations on the computer.

\subsection{Data Analysis}

The data obtained from the results of surveys and interviews using questionnaires as a reference for interviews with red rice farmers and then processed using tabulation and data analysis.

Explanation:

$$
\text { Prt }=\text { Pon-fp }+ \text { Pon-fnp }+ \text { Pof-f }+ \text { Pnon- } f
$$

Prt $=$ Household income

Pon- $\mathrm{fp}=$ Red rice farming income

Pon-fnp $=$ Farming income other than rice red

Pof- $\mathrm{f}=$ Income other than farming (farming results)

Pnon- $\mathrm{f}=$ Income other than agriculture

$$
K=P d i / T P d X 100 \%
$$

Explanation:

$\mathrm{K}=$ Contribution $(\%)$

$\mathrm{Pdi}=$ Farming income (IDR/harvest/month)

$\mathrm{TPd}=$ Total household income (IDR/month)

Explanation:

$$
P F=P P / T P X 100 \%
$$

$\mathrm{PF}=$ Share of food expenditure $(\%)$

$\mathrm{PP}=$ Food expenditure (IDR/year)

$\mathrm{TP}=$ Household expenditure (food and non-food) (IDR/year)

$\mathrm{PF} \leq 60 \%$ of total expenditure, meaning that the household is in the food security category

$\mathrm{PF} \geq 60 \%$ of total expenditure, meaning that the household is categorized as food insecure

Explanation:

$$
D B P P=T P /(T E-B U)
$$

DBPP $=$ Purchasing power of farmer households

$\mathrm{TP}=$ Total income of farmer households from all sources (IDR/year) 
$\mathrm{TE}=$ Total household expenditure of farmers (IDR/year)

$\mathrm{BU}=$ Farming costs

DBPP criteria. as follows:

DBPP $<1$ is classified as not prosperous

DBPP $>1$ is classified as prosperous

$$
N T P=Y / E
$$

Description :

$\mathrm{Y}=\mathrm{Y}_{\mathrm{P}}+\mathrm{Y}_{\mathrm{NP}}$

$\mathrm{E}=\mathrm{E}_{\mathrm{p}}+\mathrm{E}_{\mathrm{k}}$

Explanation:

$\mathrm{Y}=$ Price index received by farmers

$\mathrm{Y}_{\mathrm{P}}=$ Total agricultural income

$\mathrm{Y}_{\mathrm{NP}}=$ Total non-agricultural income

$\mathrm{E}=$ Price index paid by farmers

$\mathrm{E}_{\mathrm{P}}=$ Total agricultural expenditure

$\mathrm{E}_{\mathrm{K}}=$ Total non-agricultural expenditure

NTP criteria. as follows:

NTP $<1$ is classified as not prosperous

NTP $>1$ is classified as prosperous

\section{Result And Discussion}

\subsection{Identity of Respondents}

Farmers are the main figures who have a role in farming activities starting from land processing until harvesting arrives. The identity of farmers is important to find out how big the criteria for red rice farmers are in Panggang District. The identity of the farmers analyzed included age, gender, last education, and farming experience. Farmers who were used as respondents were 100 red rice farmers in Girisekar, Girimulyo, Girikarto, and Giriwungu villages in Panggang District.

\subsubsection{Age}

Age is an influential factor in determining the mindset and physical abilities of farmers to run the farm. This is because the mindset and physical abilities of productive age affect the success of farming so that it can increase the production of cultivated plants. One of the indicators in measuring whether or not an entrepreneur is productive in managing his business is age[18]. Data regarding the profile of red rice farmers by age can be seen in Table 4.

Based on table 4, it can be seen that the age of red rice farmers in Panggang District is mostly at the age of $50-61$ years which reaches $45.00 \%$ with the number of farmers as many as 45 people. Meanwhile, at least at the age of $62-73$ years this only has a percentage of $7.00 \%$ with a total of 7 farmers. Currently the regeneration of farmers is still lacking and many productive age who depend on work in fields other than agriculture because according to them the income will be more if they work other than being farmers.

Revealed that in their research area the average age of farmers is between 31 - 40 years, with productive age it is expected that farmers have stronger physical abilities so that the contribution of labor will be greater[18]. If according to labor law no. 13 of 2003, the productive age is between the ages of 15 - 64 years. It can be said that red rice farmers in 
Panggang District are of productive age. So that the mindset that continues to grow will affect the skills and knowledge in farming.

Table 4. Profile of dry land red rice farmers in Panggang District by age

\begin{tabular}{|c|l|r|r|}
\hline No & Age (Years) & Farmers (Persons) & Percentage (\%) \\
\hline 1 & $26-37$ & 16 & 16.00 \\
\hline 2 & $38-49$ & 32 & 32.00 \\
\hline 3 & $50-61$ & 45 & 45.00 \\
\hline 4 & $62-73$ & 7 & 7.00 \\
\hline
\end{tabular}

\subsubsection{Education Level}

Education is important to increase knowledge and insight. For this reason, the level of education in an area is useful in increasing farm production results. If farmers' education is low, it will hinder farmers in obtaining information and it will take a long time to develop technology and innovation.

Table 5. Profile of dry land red rice farmers in Panggang District based on education level

\begin{tabular}{|c|c|c|c|}
\hline No & Education Level & Farmers (Persons) & Percentage (\%) \\
\hline 1 & No School & 10 & 10.00 \\
\hline 2 & Elementary School & 53 & 53.00 \\
\hline 3 & Junior High School & 29 & 29.00 \\
\hline 4 & Senior High School & 8 & 8.00 \\
\hline \multicolumn{2}{|l|}{ Total } & 100 & 100,00 \\
\hline
\end{tabular}

Based on table 5, it can be seen that the last education of many farmers who finished elementary school was $53.00 \%$ with the number of farmers being 53 people. This is because there is not enough money to continue education to the next level. In this case, farmers in Panggang District still think that if they are farmers, they do not need to continue their higher education. Because of elementary school education, you can also become a farmer and get a job. However, not all farmers think like that, some farmers can also continue their higher education such as junior high and high school. According to Nurhayati and Sahara that the higher a person's level of education, the development of technology and one's abilities will be much more responsive[25]. It can be said that the level of education in Panggang District is still lower, but the existence of relationships will increase the knowledge and insight of farmers.

\subsubsection{Long time farming}

Farming experience is one of the factors that can affect the sustainability of farmers. The longer the experience of farming, the more insight and knowledge gained, especially in the field of red rice. However, those who still have new experience in farming do not rule out the possibility that there is not much knowledge and insight in the field of agriculture.

Table 6. Profile of dry land red rice farmers in Panggang District based on length of

\begin{tabular}{|c|l|r|r|}
\hline No & Age (Years) & Farmers (Persons) & \multicolumn{1}{c|}{ Percentage (\%) } \\
\hline 1 & $3-15$ & 30 & 30.00 \\
\hline 2 & $16-28$ & 28 & 28.00 \\
\hline 3 & $29-41$ & 36 & 36.00 \\
\hline 4 & $42-54$ & 6 & 6.00 \\
\hline \multicolumn{2}{|c|}{ Total } & $\mathbf{1 0 0}$ & $\mathbf{1 0 0 , 0 0}$ \\
\hline
\end{tabular}


Table 6 shows that at the age of 29 - 41 years is the most experienced with the number of farmers 36 people and the percentage is $36.00 \%$. More experience of farmers will increase the knowledge and insight of farmers. That although farmers' education is low but having longer farming experience will help success in farming[18]. This is because the higher the experience of farming, the more accustomed they are to dealing with risks and able to know the solution to problems if experienced during farming.

\subsubsection{Gender}

Gender is one of the factors that affect farm production in the Panggang district. Similar to the workforce, men are more dominant than women.

Table 7. Profile beraas red rice farmers dry land in the District Bakeby type of gender

\begin{tabular}{|c|l|c|c|}
\hline No. & Gender & Farmers (Persons) & Percentage (\%) \\
\hline 1 & Male & 45 & 45.00 \\
\hline $\mathbf{2}$ & Female & $\mathbf{5 5}$ & $\mathbf{5 5 . 0 0}$ \\
\hline \multicolumn{2}{|c|}{ Total } & 100 & 100.00 \\
\hline
\end{tabular}

Table 7 explains that the largest number of farmers in Panggang District are women, as many as 55 people with a percentage of $55.00 \%$. Women who do farming actually work as housewives and traders. However, they also help their husbands to cultivate the agricultural land. In addition, there are many women's farmer groups in each village, one of which is in Girisekar Village, namely the Pucang Asri farmer group with 28 members. This is comparable to the statement which states that the male farmer as the head of the household is closely related to the level of food security. Farm households with female heads of household tend to have high food problems[19]. This is because women are involved in generating total household income. Households headed by men sometimes migrate to look for other work opportunities, while households headed by women usually stay in the village and pay attention to cultivation plant[27].

\subsubsection{Land Area}

Land is an important factor in farming that can affect agricultural production. The more land that is cultivated, the more production is produced. The following table shows the average land area in Panggang District.

Table 8 explains that most dominating agricultural land is between $200-1650 \mathrm{~m}^{2}$ with a number of owners of 82 people and a percentage of $82.00 \%$. The average area of land cultivated by farmers in Panggang District is $1,078 \mathrm{~m}^{2}$. The land area is arable land for food crops such as rice, red rice, corn, cassava, peanuts, and soybeans. The condition of land owned by farmers in Panggang District is divided into two land conditions, namely sloping land and sloping land.

Table 8. Profile of dry land red rice farmers in Panggang District based on land ownership

\begin{tabular}{|c|l|r|r|}
\hline No & Land Area $\left(\mathbf{m}^{\mathbf{2}}\right)$ & Farmers $($ Persons) & Percentage $\mathbf{( \% )}$ \\
\hline $\mathbf{1}$ & $\mathbf{2 0 0}-\mathbf{1 6 5 0}$ & $\mathbf{8 2}$ & $\mathbf{8 2 . 0 0}$ \\
\hline 2 & $1651-3101$ & 13 & 13.00 \\
\hline 3 & $3102-4552$ & 2 & 2.00 \\
\hline 3 & $4553-6003$ & 3 & 3.00 \\
\hline Total & $\mathbf{1 0 0}$ & $\mathbf{1 0 0 , 0 0}$ \\
\hline
\end{tabular}


The wider the land ownership, the higher the yield of agricultural production and farmers' income. Conversely, the narrower the area of land ownership, the lower the yield of agricultural production and farmers' income. Previous research stated thatthat the variable land area has a very significant effect on the production of lowland rice farming in the village of Bonemarawa[21].

\subsection{Farmer's Household Income Analysis}

Farmer's household income is the income obtained from red rice farming, non-red rice farming, and non-farming income. This income is obtained from work in one year.

Table 9. Analysis of farmer household income in Panggang District

\begin{tabular}{|c|l|r|r|r|r|}
\hline \multirow{2}{*}{ No. } & \multirow{2}{*}{ Description } & \multicolumn{2}{c|}{ Before Covid-19 } & \multicolumn{2}{c|}{ During Covid-19 } \\
\cline { 3 - 6 } & & \multicolumn{1}{c|}{ (IDR) } & \multicolumn{1}{c|}{$(\boldsymbol{\%})$} & \multicolumn{1}{c|}{ (IDR) } & \multicolumn{1}{c|}{$\mathbf{( \% )}$} \\
\hline 1 & Income of Red Rice & 920,332 & 4.15 & 646,274 & 3.42 \\
\hline 2 & On farm & $1,563,606$ & 7.05 & 678,392 & 3.59 \\
\hline 3 & Off Farm & $2,388,000$ & 10.76 & $2,106,000$ & 11.13 \\
\hline 4 & Non-farm & $17,319,600$ & 78.05 & $15,490,200$ & 81.87 \\
\hline \multicolumn{2}{|c|}{ Total } & $\mathbf{2 2 , 1 9 1 , 5 3 8}$ & $\mathbf{1 0 0 . 0 0}$ & $\mathbf{1 8 , 9 2 0 , 8 6 7}$ & $\mathbf{1 0 0 . 0 0}$ \\
\hline
\end{tabular}

Table 9 shows that the household income of farmers tends to decrease. The difference in total income between before Covid-19 and during Covid-19 is IDR. 3,270,671. The highest income is still obtained from non-farm income, namely before Covid-19 of IDR. 17,319,600 and during Covid-19 IDR. 15,490,200. This means that in meeting household needs, farmers look for other jobs. In line with research which revealed that although not all household heads earn income from non-farming, this income is needed to meet household needs[28]. farmer household needs. Meanwhile, housewives have no other job besides helping her husband work in the fields and taking care of the housework. Previous research stated that the loss of red rice production caused by pests that attack rice crops in $10 \%$ of rice acreage in China, India and Vietnam amounting to 40 million rations of rice lost globally each year, which in turn will undermine regional efforts to increase rice production[29]. Therefore the production of red rice is low.

The decline in income that occurred during Covid-19 was due to widespread social restrictions in the form of closing transportation routes, trade, and social restrictions in the form of reducing the number of workers in a job field. Supported by previous research which states that the scarcity of labor both local workers and migrant workers is the impact of lockdowns in various parts of the world that have an impact on the movement of agricultural and raw livestock products[23].

\subsection{Contribution Analysis}

Contribution is the amount of contribution given from a job to family income. The contribution of farmers' income is enough to help farmers' household income. When the prices of daily necessities and some commodities increase, farmers feel that they can still contribute to increasing household income. This situation encourages farmers to make maximum use of their land.

The results of the calculation of table 10 show that the contribution of farmers in Panggang District has decreased. The contribution difference between before Covid-19 and during Covid- 19 was $0.73 \%$. This percentage shows that the contribution value of farmers' income is still very low because it is less than the set criteria, namely $25 \%$. The most decrease was obtained from non-farm income with the difference between before and 
during Covid-19 of IDR. 1,289,400. Non-farm income is said to have decreased because during Covid-19, jobs that interact and tend to have associations with many people are given restrictions in the form of reducing labor and regional restrictions. Therefore, farmers whose income is obtained from non-farm have decreased.

Table 10. Analysis of farmer household income contribution in Panggang District

\begin{tabular}{|c|l|c|c|c|r|}
\hline \multirow{2}{*}{ No } & \multicolumn{2}{|c|}{ Description } & \multicolumn{2}{c|}{ Before Covid-19 } & \multicolumn{2}{c|}{ During Covid-19 } \\
\cline { 3 - 6 } & & (IDR) & $\mathbf{( \% )}$ & \multicolumn{1}{c|}{ (IDR) } & (\%) \\
\hline 1 & Income of Red Rice(a) & 920,332 & 4.15 & 646,274 & 3.42 \\
\hline 2 & On farm (b) & $1,563,606$ & 7.05 & 678,392 & 3.59 \\
\hline 3 & Off Farm (c) & $2,388,000$ & 10.76 & $2,106,000$ & 11.13 \\
\hline 4 & Non-farm (d) & $17,319,600$ & 78.05 & $15,490,200$ & 81.87 \\
\hline $\mathbf{5}$ & Income of Household (e) & $\mathbf{2 2 , 1 9 1 , 5 3 8}$ & $\mathbf{1 0 0 . 0 0}$ & $\mathbf{1 8 , 9 2 0 , 8 6 7}$ & $\mathbf{1 0 0 . 0 0}$ \\
\hline & Contribution (\%) ((a/e)*100) & $\mathbf{4 . 1 5}$ & & $\mathbf{3 . 4 2}$ & \\
\hline
\end{tabular}

The lowest contribution decrease was obtained from red rice farming income. The difference in contributions between before Covid-19 and during Covid-19 was IDR 274,058 . The decrease was due to a decrease in some costs that were actually incurred such as fertilizers, seeds, pesticides, TKLK costs. In addition, pests that attack red rice farming make the amount of red rice production decrease.

Based on field observations, the contribution of farmers' income is sufficient for the daily needs of farmer households. For this reason, farmers always try to fulfill their household needs by seeking other sources of income. This is in line with previous research which stated that the contribution of farmers obtained from her research is $4.47 \%$. Although the contribution is not large, farming activities are still considered quite important in increasing farmer household income[24].

\subsection{Food Security Analysis}

Household food security is carried out using the food expenditure share approach. The following is the level of food security of farmer households in Panggang District.

Table 11. Analysis of food security in Panggang District based on the share of food expenditure

\begin{tabular}{|c|c|c|c|}
\hline No. & Description & Before Covid-19 & During Covid-19 \\
\hline 1 & Food Expenditure (a) & $6,266,040$ & $5,705,100$ \\
\hline 2 & Total Expenditure of Household (b) & $14,115,372$ & $11,442,763$ \\
\hline & PPP \% ((a/b)*100) & $\mathbf{4 4 . 3 9}$ & $\mathbf{4 9 . 8 6}$ \\
\hline
\end{tabular}

Based on Table 11, it can be seen from the food expenditure share (PPP) approach, it shows that the percentage of PPP before Covid-19 and during Covid-19 was $60 \%$. This figure means that farmer households are included in the food security category. However, as long as Covid-19 experienced an increase in PPP, the increase was close to the number of food insecurity. There is a possibility that food security during Covid-19 in the food insecurity category will also increase.

Household spending is higher because there are many school ages, both kindergarten, elementary, junior high, high school, and college. School age before Covid-19 incurred a large amount of money because the learning system was carried out face-to-face. The results of their research showed low food and non-food expenditures because many children were still at school age as a result non-food expenditures were dominated by children's education and transportation costs[21]. Food expenditure decreased during Covid-19 because during social restrictions, many residents met their food needs with their 
own farm produce such as fruits and vegetables. The following is the food security of farmer households in Panggang District based on population.

Table 12. Food security based on population in Panggang District

\begin{tabular}{|c|c|r|r|r|r|}
\hline \multirow{2}{*}{ No } & \multirow{2}{*}{ Description } & \multicolumn{2}{|c|}{ Before Covid-19 } & \multicolumn{2}{c|}{ During Covid-19 } \\
\cline { 3 - 6 } & & (Farmer) & \multicolumn{1}{c|}{$(\boldsymbol{\%})$} & (Farmer) & \multicolumn{1}{c|}{$\boldsymbol{( \% )}$} \\
\hline 1 & Food resistant $(\leq 60 \%)$ & 72 & 72.00 & 68 & 68.00 \\
\hline 2 & Food insecurity $(>60 \%)$ & 28 & 28.00 & 32 & 32.00 \\
\hline & Total & $\mathbf{1 0 0}$ & $\mathbf{1 0 0 . 0 0}$ & $\mathbf{1 0 0}$ & $\mathbf{1 0 0 . 0 0}$ \\
\hline
\end{tabular}

Table 12 explains that before and during Covid-19 the food resistant category was higher. This figure shows that the share of food expenditure for each farmer household is $60 \%$. Before Covid-19, $72 \%$ of households were in the food resistant category while the remaining $28 \%$ were in the food insecurity category. Similar to the results during Covid-19, namely $68 \%$ of households in the food resistant category and $32 \%$ in the food insecurity category. The household food expenditure of farmers in Panggang District is lower than non-food expenditure. The share of food expenditure in Seyegan District is $76 \%$ which shows the share of food expenditure is $<60 \%$ of total expenditure[25].

The study confirms that the greater the expenditure of the farmer's household, the higher the level of food security of the farmer's household towards the category of food insecurity. Previous research stated that the remaining households $(14.3 \%)$ were food insecure for some time including 5.6\% very low food security, meaning that the food intake of one or more household members was reduced and the pattern of food security was reduced[31]. Their feeding is sometimes interrupted throughout the year because households lack money and other resources for food.

\subsection{Farmer Household Welfare}

\subsubsection{Farming Household Purchasing Power Level (DBPP)}

The purchasing power of farmer households is the result of dividing the total income by the total expenditure of the farmer households other than farming. The analysis of the level of purchasing power of farmers' households will show indicators of farmer's economic welfare. The higher the level of purchasing power of farmers, the better access of farmers to food, so that the level of family food security is also better. The level of purchasing power of farmer households based on land strata can be seen in the following Table 13.

Table 13. The level of purchasing power of farmer households in Panggang District

\begin{tabular}{|c|l|r|r|}
\hline No & \multicolumn{1}{|c|}{ Description } & Before Covid-19 & During Covid-19 \\
\hline 1 & Total income of Household's Farmer(a) & $22,191,538$ & $18,920,867$ \\
\hline 2 & Total Expenditure of Household (b) & $14,115,372$ & $11,442,763$ \\
\hline 3 & Farm cost (c) & $2,131,352$ & $2,048,653$ \\
\hline DBPP $(\mathbf{a} /(\mathbf{b}-\mathbf{c}))$ & $\mathbf{1 . 8 5}$ & $\mathbf{2 . 0 1}$ \\
\hline
\end{tabular}

Based on Table 13, it can be seen that the total level of purchasing power of farmer households has increased. The difference in the increase in the level of purchasing power between before Covid-19 and during Covid-19 was 0.16\%. Income during Covid-19 has decreased due to limited access to jobs, so spending has also decreased. The results of the level of purchasing power before and during Covid-19 showed a number $>1$, meaning that farmer households received greater income than the expenditures incurred by farmers. The greater the income earned by farmers, the household expenses and farm costs will also be greater and the value of household purchasing power will be smaller. Conversely, the 
smaller the income earned by farmers, the household expenses and farm costs will also be smaller and the value of household purchasing power will be greater.

The average purchasing power of rice farmer households in Buahdua Village was 2.24[32]. The larger the land owned, the greater the purchasing power of the farmer's household. Because the wider the area of land used, the greater the income earned by farmers. So, it can be said that the wider the land owned by the farmer, the higher the level of welfare of the farmer.

Table 14. Welfare of farmer households with indicators of purchasing power of farmer households based on population

\begin{tabular}{|c|c|c|c|c|c|}
\hline \multirow{2}{*}{ No } & \multirow{2}{*}{ Description } & \multicolumn{2}{|c|}{ Before Covid-19 } & \multicolumn{2}{c|}{ During Covid-19 } \\
\cline { 3 - 6 } & & (Farmer) & $\mathbf{( \% )}$ & (Farmer) & $\mathbf{( \% )}$ \\
\hline 1 & Prosperous $>1$ & 60 & 60.00 & 57 & 57.00 \\
\hline 2 & No Prosperous $<1$ & 40 & 40.00 & 43 & 43.00 \\
\hline & Total & $\mathbf{1 0 0}$ & $\mathbf{1 0 0 . 0 0}$ & $\mathbf{1 0 0}$ & $\mathbf{1 0 0 . 0 0}$ \\
\hline
\end{tabular}

Table 14 shows that before and during Covid-19 were dominated by farmer households in the prosperous category. However, during Covid-19 there was a decline in the prosperous category with a difference of 3 farming households from before Covid-19. This resulted in an increase in the poor category with a difference of 3 farming households during Covid-19. This change is due to differences in income, expenditure, and farm household costs of farmers. One of the changes occurred during Covid-19, where decreased income due to employment resulted in low income due to restrictions in all fields.

Be in accordance with the Covid research in Pakistan which explains that epidemics and pandemics have significant social consequences[33]. The perceived impacts include restrictions on mobility, border closures, travel bans, and regional quarantines. This restriction also affects the household finances of farmers.

\subsubsection{Farmer Household Income Exchange Rate}

The exchange rate of farmer household income (NTP) is the division between total household income and total household expenditure. The greater the value of NTP, the higher the level of farmer welfare. The table below is a farmer's NTP.

Table 15. Farmer Household Income Exchange Rate

\begin{tabular}{|c|c|r|r|}
\hline No & Description & Before Covid-19 & During Covid-19 \\
\hline 1 & Total income of Household's Farmer(a) & $22,191,538$ & $18,920,867$ \\
\hline 2 & Total Expenditure of Household (b) & $14,115,372$ & $11,442,763$ \\
\hline & NTP $(\mathbf{a} / \mathbf{b})$ & $\mathbf{1 . 5 7}$ & $\mathbf{1 . 6 5}$ \\
\hline
\end{tabular}

Based on table 15 it is explained that the percentage of NTP has increased. The increase in the percentage of NTP before Covid-19 compared to during Covid-19 was 0.08 units. The percentage of NTP shows $>1$ meaning that it is prosperous where the total expenditure of the farmer's household is smaller than the total income of the farmer's household. The lower the income, the lower the household expenditure of farmers, so the value of NTP is getting smaller. Conversely, the higher the income, the higher the household expenditure of farmers, so the value of NTP is greater.

This means that farmers are able to meet the needs for agricultural and non-agricultural businesses. The value of NTP $<1$ indicates that the total expenditure of the farmer's household is greater than the total income of the farmer's householdd [22, 34-37]. Thus, based on land ownership strata, whether households have narrow, medium, or wide land, the average value of NTP $>1$. 
Table 16. Welfare of farmer's household with indicator of exchange rate of farmer's household income based on population

\begin{tabular}{|c|c|r|r|r|r|}
\hline \multirow{2}{*}{ No } & \multirow{2}{*}{ Description } & \multicolumn{2}{|c|}{ Before Covid-19 } & \multicolumn{2}{c|}{ During Covid-19 } \\
\cline { 3 - 6 } & & Farmer) & $(\boldsymbol{\%})$ & (Farmer) & \multicolumn{1}{c|}{$\boldsymbol{( \% )}$} \\
\hline 1 & Prosperous $>1$ & 60 & 60.00 & 58 & 58.00 \\
\hline 2 & No Prosperous $<1$ & 40 & 40.00 & 42 & 42.00 \\
\hline & Total & $\mathbf{1 0 0}$ & $\mathbf{1 0 0 . 0 0}$ & $\mathbf{1 0 0}$ & $\mathbf{1 0 0 . 0 0}$ \\
\hline
\end{tabular}

Based on Table 16, it shows that before and during Covid-19, households were dominated by the prosperous category. There was a $2.00 \%$ decrease in the welfare category from before Covid-19. However, there was an increase in the category of not prosperous as much as $2.00 \%$. This is because some farming households experienced a decrease in income during Covid-19 so that food and non-food expenditures also decreased. Based on field observations, it was found that farmers' expenditures before Covid-19 tended to be mostly due to school needs. During Covid-19, the need for schools such as communication facilities has increased. In addition, farm production has decreased and the need for food other than rice has increased.

\section{Conclusion and Recommendation}

\subsection{Conclusion}

The impact caused during Covid-19 on the contribution of farmer household income, namely a decrease in income contribution. Before Covid-19, the contribution was $4.15 \%$ while during Covid-19 it was $3.42 \%$. This figure is still included in the very low category. The lowest income is obtained from on-farm red rice while the highest income is obtained from non-farm income. The impact caused during the Covid-19 outbreak on the food security of farmer households was that there was a change during Covid-19, namely the increase in the number of farmer households into the food insecure category. The impact caused during Covid-19 on the welfare level of farmer households, namely from two indicators that obtained the same results, namely a change from before Covid-19 to during Covid-19. The changes that occur are the increase in farmer households that are categorized as not prosperous.

\subsection{Recommendation}

Optimizing the productivity of red rice planted on dry land in order to increase farmers' income obtained from on farm income.

Acknowledgements. The highest appreciation is conveyed to PT. Indofood Sukses Makmur Tbk. in one of the Corporate Social Responsibility (CSR) programs, namely Indofood Research Nugraha which has provided research funding assistance to author in order to complete the final project/thesis.

\section{Reference}

1. S. Hanoatubun, J. Educ. Psychol. Couns. 2, 146 (2020).

2. F. Amanta and I. Aprilianti, CIPS Cent. Indones. Policy Stud. 2020, 1 (2020).

3. R. Prabowo, Mediagro 62, 62 (2010). 
4. Martina and R. Praza, J. Agrifo 3, 27 (2018).

5. J. Wardie, J. Agros 17, 153 (2015).

6. E. Hernawan and V. Meylani, J. Kesehat. Bakti Tunas Husada 15, 79 (2016).

7. BPS, Badan Pus. Stat. Kabupaten Gunungkidul 39, 1 (2019).

8. Kristamini dan Purwaningsih H, J. Litbang Pertan. 28, 88 (2009).

9. BPS, Analisis Kemiskinan Kabupaten Gunungkidul (2019).

10. M. Rizou, I. M. Galanakis, T. M. S. Aldawoud, and C. M. Galanakis, Trends Food Sci. Technol. 102, 293 (2020).

11. P. Udmale, I. Pal, S. Szabo, M. Pramanik, and A. Large, Prog. Disaster Sci. 7, 100120 (2020).

12. A. Patunru, G. Octania, and P. Audrine, Cent. Indones. Policy Stud. 1 (2020).

13. D. Reyes-olavarr, Á. Pedro, I. Paola, D. Jerez-mayorga, F. Caamaño-navarrete, and P. Delgado-floody, Int. J. Environ. Res. Public Heal. 1 (2020).

14. M. M. D. Syafi'ie, J. Produksi Tanam. 6, 1028 (2018).

15. A. R. Bertuso, R. van Treuren, F. A. van Eeuwijk, and L. Viseer, Plant Genet. Resour. Newslatter 1 (2009).

16. Kristamtini and H. Purwaningsih, J. Litbang Pertan. 28, 88 (2009).

17. Kristamtini and Prajitno AL, J. Ilmu-Ilmu Pertan. 5, 45 (2009).

18. B. K. P. K. Pertanian, Badan Ketahanan Pangan Kementrian Pertan. 1 (2018).

19. S. Aminah, J. Bina Praja 7, 197 (2015).

20. M. S. Boori, K. Choudhary, R. A. Paringer, and M. Evers, Comput. Opt. 41, 552 (2017).

21. M. Wahed, F. E. Bisnis, and U. B. Malang, JESP 7, 68 (2015).

22. A. Alfrida and T. I. Noor, Agroinfo Galuh 4, 426 (2017).

23. M. T. Sugesti, Z. Abidin, and U. Kalsum, J. Ilmu-Ilmu Agribisnis 3, 268 (2015).

24. D. Rochdiani, K. Kusno, and B. R. Saefudin, ISBN 263 (2007).

25. R. Yulida, Indones. J. Agric. Econ. 3, 135 (2012).

26. M. I. Bahua, Agroekonomika 3, 133 (2014).

27. S. Abdalla, I. Leonhäuser, S. Bauer, and E. Elamin, Sky J. Agric. Res. 2, 88 (2013).

28. 2BKP, Peta Ketahanan Dan Kerentanan Pangan 2019 (Badan Ketahanan Pangan, 2019).

29. A. Durand-Morat, L. L. Nalley, and G. Thoma, Glob. Food Sec. 18, 62 (2018).

30. J. H. Mulyo, Sugiyarto, and A. W. Widada, Agro Ekon. 26, 121 (2015).

31. A. Coleman-Jensen, C. Gregory, and A. Singh, United States Dep. Agric. Econ. (2014).

32. A. Arida, Sofyan, and K. Fadhiela, J. Agrisep Unsyiah 16, 20 (2015).

33. A. Ali and O. Erenstein, Clim. Risk Manag. 16, 183 (2017).

34. Z. Rozaki, Indardi, Triyono, I. Salassa, and R. B. Nugroho. Farmers' responses to organic rice farming in Indonesia: Findings from central Java and south Sulawesi. Open Agric. 2020, 5, 703-710.

35. Z. Rozaki. Covid-19, Agriculture and Food Security in Indonesia. Reviews in Agricultural Science. 2020, 8, 243-260.

36. Triyono, N. Rahmawati, and Z. Rozaki. Sustainable value of rice farm based on 
economic efficiency in Yogyakarta, Indonesia. Open Agric. 2021, 6, 563-572.

37. Winarno, B. Neoliberal Policy of Indonesia's Agricultural Revitalization. Jurnal Hubungan Internasional. 2016, 5, 31-39. 